\title{
Analysis of the implementation of Indonesia Financial Accounting Standards number 109 at the National Management Agency of West Kalimantan Province
}

\author{
Baidhillah Riyadhi, ${ }^{1}$ Henri Prasetyo, ${ }^{2}$ Fiorintari ${ }^{3}$ \\ 1,2,3Politeknik Negeri Pontianak, Indonesia \\ email: baidhillahriyadhi@student.upi.edu
}

\begin{abstract}
Purpose - This research aims to determine the implementation of Indonesia Financial Accounting Standards (PSAK) 109 at the National Zakat Management Agency (Baznas) of West Kalimantan Province.

Method - The research was conducted using a qualitative descriptive research method to describe events in the research field, in the form of reports and distribution of Zakat, Infaq and Shadaqah (ZIS) in 2017 and 2018, then compared with PSAK 109.

Result - The results showed that the implementation of PSAK 109 in the recognition and measurement section of Baznas in West Kalimantan Province can be stated in accordance with PSAK 109. Meanwhile, the implementation of PSAK 109 in the presentation, disclosure and component of financial statements in Baznas of West Kalimantan Province has not fully implemented PSAK 109 as a whole.

Implication - The implication of this research is expected to help Baznas of West Kalimantan Province in implementing PSAK 109 so that public trust can increase in themanagement of ZIS funds.

Originality - The uniqueness of this research compared to several previous researches can be seen from the object of research that was first conducted at Baznas of West Kalimantan Province and the research used the data in the last 2 years.
\end{abstract}

Keywords: PSAK 109; ziswaf; national zakatmanagement agency 
Baidhillah Riyadhi, Henri Prasetyo, Fiorintari

\section{Introduction}

The potential for national zakat is quite large, citing information from the Head of Baznas of West Kalimantan Province, H. Didik Imam Wahyudi, based JIAFR | 92 on the calculation of the Zakat Potential Mapping Indicator (IPPZ), the potential for zakat in Indonesia that can be collected by Baznas is IDR 233.8 trillion (Wahyudi, 2020). In fact, the Head of Regional Office (Kanwil) of the Ministry of Religious Affairs (Kemenag) of West Kalimantan, Drs. H. Ridwansyah said that the potential for zakat in West Kalimantan reached 2,104 trillion rupiah (Irwanto, 2019). The large potential of zakat is expected to reduce the inequality in Indonesian society, because the poor are parts of mustahik zakat (people who deserve to receive zakat).

Public trust in zakat management agencies occupies an important position for the success of Baznas in collecting and managing zakat, infaq and shadaqah (Nurhasanah, 2018). Thus, it is hoped that Baznas will strive to show performance and efforts that can increase the trust of the community. However, research from Asnaini (2017) stated that the negative attitude of muzaki (people who pay zakat) towards the management of zakat by the zakat management agencies is $96.67 \%$ of the 90 respondents studied. This needs to be a concern for the zakat management agencies to improve their zakat management. This is in accordance with the suggestions of research by Rulian et al. (2014) to increase the receipt of zakat funds by increasing the accountability report in the management of zakat funds.

Zakat demands to be managed properly and correctly. In accordance with Indonesian Zakat Law (Undang-Undang Nomor 23 Tahun 2011), the government has established a National Zakat Management Agency (Baznas) to manage zakat funds. Through the agency, the government is here to manage zakat funds from the Muslims. The National Zakat Management Agency (Baznas) of West Kalimantan Province collects and distributes zakat, infaq and shadaqah funds from Muslims who live in West Kalimantan. Clear and complete rules/standards are required in the reporting of financial reports on the management of zakat, infaq and shadaqah from Baznas in 
order to achieve good public accountability. This is in line with the research by Fathony \& Fatimah (2017) which shows that the rules/standards have an influence on public accountability.

Indonesia Financial Accounting Standards (PSAK) is prepared as a standard for financial management agencies or organizations. Records related to zakat, infaq and shadaqah have been regulated PSAK 109 (2018). This standard aims to regulate the recognition, measurement, presentation and disclosure of zakat, infaq and shadaqah transactions. Therefore, it is hoped that agencies that manage zakat and infaq/shadaqah funds such as Baznas at the provincial/district/city level can apply PSAK 109 which refers to the fatwa of the Shari'ah Supervisory Board (DPS) of The Council of Indonesian Ulama (MUI). PSAK 109 has not been widely applied by amil zakat agencies (Affandi \& Riswanto, 2018; Ngoyo \& Bulutoding, 2016; Rahman, 2015; Ritonga, 2017; Rizal et al., 2017). Prior to the existence of PSAK 109, zakat management institutions had made reports but there was no uniformity between one zakat management agency and other zakat management agencies. This makes it very difficult for various parties to read the purposes and objectives of the financial statements. Therefore, it is important to implement PSAK 109 in zakat management agencies. West Kalimantan Provincial Baznas itself uses PSAK 109 in 2017 because it is very important for zakat management agencies to apply the current PSAK 109 so that the financial information generated is accurate and can be used by interested parties for these financial statements. This is a problem and a question, does Baznas of West Kalimantan Province apply PSAK 109 in reporting the management of its zakat, infaq and shadaqah funds?

\section{Literature Review}

\section{Concept of Zakat}

Zakat according to Arabic comes from the word "zaka" which is blessing, growing, being holy, and being praised. Zakat is taken from some of the excessive assets of people and distributed to those who are in need. According to PSAK 109 (2018), zakat is an asset that must be issued by 
muzaki according to sharia provisions and is given to those who deserve to receive it (mustahik). Zakat regulates the terms of the nisab, periodic and non-periodic haul, zakat rates (qadar), and the designation.

There are two types of zakat according to Nurhayati (2013): 1) Zakat fitrah/zakat fitri is the zakat that is obliged to every Muslim after sunset at the end of the month of Ramadan. It is more important to pay before the 'Eid alFitr prayer, because if it is paid after the Eid prayer, then it will be considered as ordinary shadaqah, not zakat fitrah. As the saying of the Prophet Muhammad, "Whoever pays zakat fitri before the Eid prayer, his zakat is accepted and whoever fulfills it after the Eid prayer is considered only as shadaqah among the various shadaqah." (Narrated by Abu Daud). A Muslim is obliged to pay zakat fitrah for himself and his dependents, such as his wife, children and Muslim servants. However, it is permissible for a wife or child and the servant to pay zakat on their own. According to some scholars, the compulsory requirement for zakat fitrah is when he has excess staple food for himself and his dependents on 'Eid al-Fitr night and day. The excess does not include the house, furniture and other basic necessities including the livestock used, the books studied or the jewelry he uses. The point is, if it has exceeded and worth selling and used for zakat fitrah, then paying zakat fitrah is obligatory because he is able to pay it. 2) Property-zakat is zakat that may be paid at an unspecified time, including commercial, agricultural, mining, marine products, livestock products, amusement, gold and silver as well as professional work, each of which has its own calculation and a sufficient ratio.

\section{Infaq/Shadaqah}

Infaq means removing part of the assets or income/income for an interest ordered by Islamic teachings. Infaq includes donations to the poor of fellow Muslims, donations for natural disasters and others. Unlike zakat, infaq can be given to anyone even though it is not included in the eight asnaf (the people who deserve to receive zakat).

Shadaqah has a broader meaning than zakat and infaq. According to Indonesian Zakat Management Law (Undang-Undang Nomor 23 Tahun 
2011), shadaqah is asset or non-asset issued by a person or business entity outside of zakat for the general benefit. We as Muslims believe that we can get the reward by doing the slightest kindness called shadaqah.

\section{Accounting for Zakat, Infaq, and Shadaqah}

JIAFR | 95

Accounting for Zakat, Infaq, and Shadaqah. In general, it can be concluded that zakat accounting is the process of recognizing, measuring, presenting, and disclosing zakat, infaq/shadaqah transactions in accordance with Islamic law principles to provide information on the management of zakat, infaq/shadaqah by amil to interested parties. Accounting for zakat is related to three main things, namely the provision of information, management control, and accountability (Arwani, 2020). Accounting for zakat is an information tool between zakat management institutions as management and parties with an interest in this information. For management, zakat accounting information is used in the management control process starting from planning, programming, budget allocation, performance evaluation, and performance reporting (Mahmudi, 2008).

\section{PSAK Number 109}

The standard for zakat financial statements has been formulated by the Indonesian Accounting Association (IAI) through Indonesia Financial Accounting Standards (PSAK) Number 109 which has been ratified on April 6 , 2010. The purpose of PSAK number 109 is to regulate the recognition, measurement, presentation and disclosure of zakat transactions, donations and shadaqah. The preparation of PSAK number 109 is in accordance with sharia accounting which makes Al-Qur'an and As-Sunnah as the main basis and guidelines.

The scope of PSAK 109 is that this statement applies to people who collect and distributes zakat and infaq/shadaqah, hereinafter referred to as "amil", is a zakat management organization whose the formation is intended to collect and distribute zakat and infaq/shadaqah, and this statement does not apply to sharia entities that collect and distribute zakat and infaq/shadaqah but not 
as their main activities. The entity refers to PSAK 101: Presentation of Sharia Financial Statements.

The accounting treatment for zakat has all been regulated by PSAK number 109 which has been made by the Indonesian Accounting Association (IAI) which has been becoming effective as of January 2012. This PSAK has been regulated starting from the Recognition and Measurement of Zakat, Infaq and Shadaqah Funds, Presentation of Zakat, Infaq and Shadaqah, as well as the Disclosure of Zakat, Infaq and Shadaqah. The components of financial statement that amil of zakat must have in PSAK No. 109, namely Balance Sheet (Financial Position Report), Fund Change Report, Change in Management Assets Report, Cash Flow Statement, and Notes to Financial Statements.

\section{Baznas of West Kalimantan Province}

Referring to Indonesian Zakat Law (Undang-Undang Zakat Nomor 23 Tahun 2011), to manage zakat funds the government has formed the National Zakat Management Agency (Baznas). In the fifth part of the Zakat Law Article 29 paragraph 1, it stated that the obligation of district/city Baznas to formally produce reports on the implementation of zakat, infaq and shadaqah fund management to be submitted to the Provincial Baznas administrators and the Regional Government periodically. Thus, there is an obligation for the Zakat Management Foundation (LAZ) and the Zakat Management Agency (BAZ) to produce financial management reports. Informally, it is important to make financial reports to be submitted to the public, especially for muzaki who have given trust to BAZ to channel the assets owned by muzakki. West Kalimantan Baznas collects and distributes zakat, infaq and shadaqah funds from civil servants (PNS) who work for government agencies in the West Kalimantan region.

\section{Research Methods}

This research uses a qualitative descriptive method approach. The steps taken are: 1) determine the location of the research, 2) establish a research 
method approach, 3) determine data sources and research data collection techniques, 4) data analysis, 5) conclusion.

In the first step, the National Zakat Management Agency (Baznas) of West Kalimantan Province was appointed as the research location. The research object was determined based on observations and findings in the JIAFR | 97 field, that not all Baznas in the cities of West Kalimantan have implemented PSAK 109. In the initial plan the research location was set at the Pontianak City Baznas, but because the Pontianak City Baznas had not implemented PSAK 109, the research location moved to Baznas of West Kalimantan Province. Before determining the location of the research, the researcher had made preliminary observations and conveyed the research permission either verbally or written. Verbal permission was carried out as a preliminary research which was important to determine the response to the willingness of the Baznas of West Kalimantan Province management as information providers (informants) about the application of PSAK 109. After getting good responses to be able to continue the research, an official research permit was made in written form from the Research and Community Service Unit (UPPM) of the Pontianak State Polytechnic addressed to Baznas administrators of West Kalimantan Province.

Second, the researcher determined a qualitative descriptive method as the research method to be used. Through a qualitative descriptive method, the facts that occurred in the field/research location were described, namely the Baznas of West Kalimantan Province in implementing PSAK 109. Researchers described the implementation of zakat and infaq/shadaqah accounting at Baznas of West Kalimantan Province. The data that had been collected were analyzed through a comparison between the application of zakat and infaq/shadaqah accounting for the Baznas of West Kalimantan Province in 2017 and 2018 with the provisions stipulated in PSAK No. 109.

Third, researchers used reports on the receipt and distribution of zakat, infaq and shadaqah from the Baznas of West Kalimantan Province in 2017 and 2018, as a source of documentary data. In addition, researchers also collected data in the form of information from Baznas management in West 
Kalimantan Province, which was the primary source data, obtained from direct interviews or through communication media such as WhatsApp. Researchers also conducted field observations to collect data in general.

Fourth, researchers conducted an analysis of the collected data. In qualitative research, analysis is carried out from the beginning of data collection to the end of the research. Systematically, data analysis was carried out through: 1) Data reduction, by selecting the collected data, so that the data needed and data that are not needed in this research can be selected and sorted. 2) Presentation of data, by presenting data that had been selected from the data that had been collected. In this research, data were in the form of a table of financial statements for the National Zakat Management Agency (Baznas), West Kalimantan Province.

Fifth, the researchers concluded the results of the research by paying attention to all the data collected from the research location. So, it could be concluded if the Baznas of West Kalimantan Province has implemented PSAK 109 or has not implemented PSAK 109 completely.

\section{Results and Discussion}

The implementation of PSAK 109 at Baznas of West Kalimantan Province was reviewed from 4 (four) sections: 1) Recognition and Measurement, 2) Presentation, 3) Disclosure, 4) The Elements of Financial Statements.

\section{Recognition and Measurement}

The implementation of PSAK 109 in recognition and measurement can be reviewed from the following table.

Table 1. The Implementation of PSAK 109 in the Recognition and Measurement Section

\begin{tabular}{llll}
\hline No. & \multicolumn{1}{c}{ PSAK 109 } & \multicolumn{1}{c}{ Criteria } & $\begin{array}{l}\text { Conditions in Baznas of } \\
\text { West Kalimantan Province }\end{array}$ \\
\hline 1.1 & $\begin{array}{l}\text { Paragraph 10: } \\
\text { Zakat received from } \\
\text { muzakki is recognized } \\
\text { as an addition to }\end{array}$ & $\begin{array}{l}\text { Zakat received from } \\
\text { muzakki is recognized as } \\
\text { an addition to zakat funds } \\
\text { with provisions: }\end{array}$ & $\begin{array}{l}\text { For the criteria for point } \\
\text { one, Baznas of West } \\
\text { Kalimantan Province is in } \\
\text { accordance with PSAK 109. }\end{array}$ \\
\hline
\end{tabular}


Analysis of the implementation of Indonesia Financial Accounting Standards ...

\begin{tabular}{|c|c|c|c|}
\hline & $\begin{array}{l}\text { zakat funds: } \\
\text { (a) if in cash, then } \\
\text { according to the } \\
\text { amount received; } \\
\text { (b) if in non-cash } \\
\text { form, then according } \\
\text { to the fair value of } \\
\text { the non-cash assets. } \\
\text { Paragraph 11: } \\
\text { Determination of the } \\
\text { fair value of non-cash } \\
\text { assets received using } \\
\text { market prices. If } \\
\text { market prices are not } \\
\text { available, then other } \\
\text { fair value } \\
\text { determination } \\
\text { methods may be used } \\
\text { in accordance with } \\
\text { the relevant PSAK. }\end{array}$ & $\begin{array}{l}\text { 1. if in cash, then } \\
\text { according to the } \\
\text { amount received. } \\
\text { if in non-cash form, } \\
\text { then according to } \\
\text { the fair value of the } \\
\text { non-cash assets. } \\
\text { Determination of the } \\
\text { fair value of non- } \\
\text { cash assets received } \\
\text { using market prices. } \\
\text { If market prices are } \\
\text { not available, then } \\
\text { other fair value } \\
\text { determination } \\
\text { methods may be } \\
\text { used in accordance } \\
\text { with the relevant } \\
\text { PSAK. }\end{array}$ & $\begin{array}{l}\text { Whereas in point two, } \\
\text { Baznas of West Kalimantan } \\
\text { Province in } 2017 \text { and } 2018 \\
\text { non-cash assets were not } \\
\text { found, so the criteria for } \\
\text { point two is ignored. } \\
\text { The conclusion regarding } \\
\text { the condition of Baznas of } \\
\text { West Kalimantan Province } \\
\text { against this criterion is } \\
\text { stated to be in accordance } \\
\text { with PSAK } 109 \text {. }\end{array}$ \\
\hline 1.2 & $\begin{array}{l}\text { Paragraph 18: } \\
\text { Infaq/shadaqah } \\
\text { received as a report } \\
\text { of restricted or } \\
\text { unrestricted } \\
\text { infaq/shadaqah funds } \\
\text { in accordance with } \\
\text { the purpose of the } \\
\text { donors of } \\
\text { infaq/shadaqah in the } \\
\text { amount of: } \\
\text { (a) amount received, } \\
\text { if in noncash form; } \\
\text { (b) fair value, if in } \\
\text { non-cash form. } \\
\text { Paragraph 19: } \\
\text { Determination of the } \\
\text { fair value of non-cash } \\
\text { assets received using } \\
\text { market prices. If } \\
\text { market prices are not } \\
\text { available, then other } \\
\text { fair value } \\
\text { determination }\end{array}$ & $\begin{array}{l}\text { Infaq/shadaqah received } \\
\text { as a report of restricted } \\
\text { or unrestricted } \\
\text { infaq/shadaqah funds in } \\
\text { accordance with the } \\
\text { purpose of the donors of } \\
\text { infaq/shadaqah with } \\
\text { provisions: } \\
\text { 1. if in cash, then } \\
\text { according to the } \\
\text { amount received. } \\
\text { if in non-cash form, } \\
\text { then according to } \\
\text { the fair value of the } \\
\text { non-cash assets. } \\
\text { Determination of the } \\
\text { fair value of non- } \\
\text { cash assets received } \\
\text { using market prices. } \\
\text { If market prices are } \\
\text { not available, then } \\
\text { other fair value } \\
\text { determination } \\
\text { methods may be }\end{array}$ & $\begin{array}{l}\text { For the criter point one, } \\
\text { Baznas of West Kalimantan } \\
\text { Province is in accordance } \\
\text { with PSAK } 109 \text {. Whereas in } \\
\text { point two, Baznas of West } \\
\text { Kalimantan Province in } \\
2017 \text { and } 2018 \text { non-cash } \\
\text { assets were not found, so } \\
\text { the criteria for point two is } \\
\text { ignored. } \\
\text { The conclusion regarding } \\
\text { the condition of Baznas of } \\
\text { West Kalimantan Province } \\
\text { against this criterion is } \\
\text { stated to be in accordance } \\
\text { with PSAK } 109 \text {. }\end{array}$ \\
\hline
\end{tabular}

Journal of Islamic Accounting and Finance Research - Vol. 3 No. 1 (2021) 


\begin{tabular}{ll}
\hline methods may be used & used in accordance \\
in accordance with & with the relevant \\
the relevant PSAK. & PSAK. \\
\hline
\end{tabular}

The results of the research in the recognition and measurement section in table 1 show that the Baznas of West Kalimantan Province has implemented reporting in accordance with PSAK 109. In accordance with the criteria of PSAK 109 in the recognition and measurement section, it is showed that the recording of the receipt of zakat and infaq/shadaqah funds which cash has been recorded in accordance with the nominal received. However, regarding the recording criteria of non-cash zakat and infaq/shadaqah funds, conformity couldn't be determined with PSAK 109, because Baznas of West Kalimantan Province did not have non-cash receipt transactions of zakat and infaq/shadaqah funds. So it can be stated in general that the Baznas of West Kalimantan Province has implemented reporting in accordance with PSAK 109 in the recognition and measurement section.

\section{Presentation}

The implementation of PSAK 109 in presentation can be reviewed from the following table.

Table 2. The Implementation of PSAK 109 in the Presentation Section

\begin{tabular}{|c|c|c|c|}
\hline No. & PSAK 109 & Criteria & $\begin{array}{c}\text { Conditions in Baznas of } \\
\text { West Kalimantan Province }\end{array}$ \\
\hline 2.1 & $\begin{array}{l}\text { Paragraph 33: } \\
\text { Non-halal receipts are } \\
\text { recognized as non- } \\
\text { halal funds, which are } \\
\text { separate from zakat } \\
\text { funds, } \\
\text { infaq/shadaqah funds } \\
\text { and amil funds. Non- } \\
\text { halal assets are } \\
\text { distributed in } \\
\text { accordance with } \\
\text { sharia. }\end{array}$ & $\begin{array}{l}\text { Non-halal receipts are } \\
\text { recognized as non-halal } \\
\text { funds, which are } \\
\text { separate from zakat } \\
\text { funds, infaq/shadaqah } \\
\text { funds and amil funds } \\
\text { and are presented } \\
\text { separately in the } \\
\text { balance sheet } \\
\text { (statement of financial } \\
\text { position). }\end{array}$ & $\begin{array}{l}\text { On this criterion, non-halal } \\
\text { funds have been } \\
\text { recognized, but were } \\
\text { presented in combination } \\
\text { with amil, zakat, and } \\
\text { infaq/shadaqah funds. } \\
\text { The conclusion regarding } \\
\text { the condition of Baznas of } \\
\text { West Kalimantan Province } \\
\text { on this criterion can be } \\
\text { stated that it is not in } \\
\text { accordance with PSAK } 109 .\end{array}$ \\
\hline
\end{tabular}


Paragraph 34:

Amil presents zakat

funds,

infaq/shadaqah

funds, amil funds, and

non-halal funds

separately in the

balance sheet

(statement of

financial position).

The results of the research in the presentation section in table 2 show that the Baznas of West Kalimantan Province did not implement reporting in accordance with PSAK 109. Incorrect criteria of PSAK 109 in the presentation section showed that non-halal funds are presented in combination with amil funds, zakat, and infaq/shadaqah. So it can be stated clearly that the Baznas of West Kalimantan Province does not implement reporting in accordance with PSAK 109 in the presentation section.

\section{Disclosure}

The implementation of PSAK 109 in disclosure can be reviewed from the following table.

Table 3. The Implementation of PSAK 109 in the Disclosure Section

\begin{tabular}{llll}
\hline No. & \multicolumn{1}{c}{ PSAK 109 } & \multicolumn{1}{c}{ Criteria } & $\begin{array}{l}\text { Conditions in Baznas of West } \\
\text { Kalimantan Province }\end{array}$ \\
\hline 3.1 & Paragraph 35: & Amil must disclose the & The criteria for point (a) were \\
& Amil must disclose & following matters & not disclosed in the Financial \\
the following & related to zakat & Statements of Baznas of West \\
matters related to & transactions, but not & Kalimantan Province in 2017 \\
zakat transactions, & limited to: & and 2018. Disclosures related \\
but not limited to: & zakat distribution & to zakat distribution policies \\
(a) zakat distribution & policies, such as & are regulated in Baznas \\
policies, such as & determining the priority & regulations. \\
determining the & scale of distribution and & The criteria for points two \\
priority scale of & recipients; & and four were not disclosed \\
distribution and & distribution policy & in the Financial Statements of \\
recipients; & between amil funds and & Baznas of West Kalimantan in \\
(b) distribution policy & non-amil funds for & 2017 and 2018. The policy for \\
\hline
\end{tabular}

Journal of Islamic Accounting and Finance Research - Vol. 3 No. 1 (2021) 


\begin{tabular}{|c|c|c|c|}
\hline & $\begin{array}{l}\text { between amil funds } \\
\text { and non-amil funds } \\
\text { for zakat receipts, } \\
\text { such as percentage } \\
\text { of distribution, } \\
\text { reasons, and } \\
\text { consistency of } \\
\text { policies; } \\
\text { (c) the method of } \\
\text { determining the fair } \\
\text { value used for } \\
\text { receipt of zakat in } \\
\text { the form of non-cash } \\
\text { assets; } \\
\text { (d) details of the } \\
\text { amount of zakat fund } \\
\text { distribution, which } \\
\text { includes the amount } \\
\text { of management } \\
\text { expenses and the } \\
\text { amount of funds } \\
\text { received directly by } \\
\text { mustahiq; and } \\
\text { (e) the special } \\
\text { relationship between } \\
\text { amil and mustahiq } \\
\text { which includes: } \\
\text { (i). the character of } \\
\text { the special } \\
\text { relationship; } \\
\text { (ii). the amount and } \\
\text { type of assets } \\
\text { distributed; and } \\
\text { (iii). the percentage } \\
\text { of assets distributed } \\
\text { from total } \\
\text { disbursement during } \\
\text { the period. }\end{array}$ & $\begin{array}{l}\text { zakat receipts, such as } \\
\text { percentage of } \\
\text { distribution, reasons, } \\
\text { and consistency of } \\
\text { policies; } \\
\text { the method of } \\
\text { determining the fair } \\
\text { value used for } \\
\text { receipt of zakat in the } \\
\text { form of non-cash } \\
\text { assets; } \\
\text { details of the amount of } \\
\text { zakat fund distribution, } \\
\text { which includes the } \\
\text { amount of } \\
\text { management expenses } \\
\text { and the amount of } \\
\text { funds received directly } \\
\text { by mustahiq; and the } \\
\text { special relationship } \\
\text { between amil and } \\
\text { mustahiq which } \\
\text { includes: } \\
\text { the character of the } \\
\text { special relationship; } \\
\text { the amount and type of } \\
\text { assets distributed; and } \\
\text { the percentage of } \\
\text { assets distributed from } \\
\text { total disbursement } \\
\text { during the period. } \\
\text { tho }\end{array}$ & $\begin{array}{l}\text { sharing between amil funds } \\
\text { and non-amil funds and } \\
\text { details of the amount of zakat } \\
\text { fund disbursement was } \\
\text { disclosed in the Zakat } \\
\text { Management Report. } \\
\text { The criteria for point (c) were } \\
\text { not disclosed because in } \\
\text { Baznas of West Kalimantan } \\
\text { Province there was no receipt } \\
\text { of non-cash assets. } \\
\text { The criteria for point (e) were } \\
\text { not disclosed in the Financial } \\
\text { Statements of Baznas of West } \\
\text { Kalimantan in } 2017 \text { and } 2018 . \\
\text { The special relationship } \\
\text { between amil and mustahiq } \\
\text { was not found in other } \\
\text { reports made by Baznas of } \\
\text { West Kalimantan Province. } \\
\text { The conclusion regarding the } \\
\text { condition of Baznas of West } \\
\text { Kalimantan Province on this } \\
\text { criterion can be stated that it } \\
\text { is not in accordance with } \\
\text { PSAK } 109 \text {. }\end{array}$ \\
\hline 3.2 & $\begin{array}{l}\text { Paragraph } 36: \\
\text { Amil must disclose } \\
\text { the following } \\
\text { matters regarding } \\
\text { infaq/shadaqah } \\
\text { transactions, but not }\end{array}$ & $\begin{array}{l}\text { Amil must disclose the } \\
\text { following matters } \\
\text { regarding } \\
\text { infaq/shadaqah } \\
\text { transactions, but not } \\
\text { limited to: }\end{array}$ & $\begin{array}{l}\text { The criteria for point (a) were } \\
\text { not disclosed because in } \\
\text { Baznas of West Kalimantan } \\
\text { Province there was no receipt } \\
\text { of non-cash assets. } \\
\text { The criteria for points (b), (c), }\end{array}$ \\
\hline
\end{tabular}


Analysis of the implementation of Indonesia Financial Accounting Standards ...

\begin{tabular}{|c|c|c|}
\hline $\begin{array}{l}\text { limited to: } \\
\text { (a) the method of } \\
\text { determining the fair } \\
\text { value used to receive } \\
\text { infaq/shadaqah is in } \\
\text { the form of non-cash } \\
\text { assets; } \\
\text { (b) distribution policy } \\
\text { between amil funds } \\
\text { and non-amil funds } \\
\text { for receiving } \\
\text { infaq/shadaqah, such } \\
\text { as percentage of } \\
\text { distribution, reasons, } \\
\text { and consistency of } \\
\text { policies; } \\
\text { (c) Infaq/shadaqah } \\
\text { distribution policies, } \\
\text { such as determining } \\
\text { the priority scale for } \\
\text { distribution and } \\
\text { recipients; } \\
\text { (d) the existence of } \\
\text { infaq/shadaqah } \\
\text { funds that are not } \\
\text { directly distributed } \\
\text { but managed first, if } \\
\text { any, then the } \\
\text { amount and } \\
\text { percentage of all } \\
\text { infaq/shadaqah } \\
\text { receipts must be } \\
\text { disclosed during the } \\
\text { reporting period and } \\
\text { the reasons thereof; } \\
\text { (e) the results } \\
\text { obtained from the } \\
\text { management } \\
\text { referred to in letter } \\
\text { (d) are disclosed } \\
\text { separately; } \\
\text { (f) the use of } \\
\text { infaq/shadaqah } \\
\text { funds becomes a }\end{array}$ & $\begin{array}{l}\text { the method of } \\
\text { determining the fair } \\
\text { value used to receive } \\
\text { infaq/shadaqah is in the } \\
\text { form of non-cash } \\
\text { assets; } \\
\text { distribution policy } \\
\text { between amil funds and } \\
\text { non-amil funds for } \\
\text { receiving } \\
\text { infaq/shadaqah, such as } \\
\text { percentage of } \\
\text { distribution, reasons, } \\
\text { and consistency of } \\
\text { policies; } \\
\text { Infaq/shadaqah } \\
\text { distribution policies, } \\
\text { such as determining the } \\
\text { priority scale for } \\
\text { distribution and } \\
\text { recipients; } \\
\text { the existence of } \\
\text { infaq/shadaqah funds } \\
\text { that are not directly } \\
\text { distributed but } \\
\text { managed first, if any, } \\
\text { then the amount and } \\
\text { percentage of all } \\
\text { infaq/shadaqah } \\
\text { receipts must be } \\
\text { disclosed during the } \\
\text { reporting period and } \\
\text { the reasons thereof; } \\
\text { the results obtained } \\
\text { from the management } \\
\text { referred to in letter (d) } \\
\text { are disclosed } \\
\text { separately; } \\
\text { the use of } \\
\text { infaq/shadaqah funds } \\
\text { becomes a managed } \\
\text { asset designated for } \\
\text { those entitled, if any, } \\
\text { the amount and }\end{array}$ & $\begin{array}{l}\text { and (h) were not disclosed in } \\
\text { the Financial Statements of } \\
\text { Baznas of West Kalimantan in } \\
2017 \text { and 2018. The } \\
\text { distribution policy between } \\
\text { amil funds and non-amil } \\
\text { funds and the policies and } \\
\text { details of the distribution of } \\
\text { infaq/shadaqah were } \\
\text { disclosed in the Zakat } \\
\text { Management Report. } \\
\text { The criteria for points (d), (e), } \\
\text { (f), and (g) were not disclosed } \\
\text { because the Baznas of West } \\
\text { Kalimantan Province did not } \\
\text { explain them in the } \\
\text { management report of } \\
\text { infaq/shadaqah fund. } \\
\text { The criteria for point (i) were } \\
\text { not disclosed in the Financial } \\
\text { Statements of Baznas of West } \\
\text { Kalimantan Province in } 2017 \\
\text { and } 2018 \text {. The special } \\
\text { relationship between amil } \\
\text { and recipients of } \\
\text { infaq/shadaqah was not } \\
\text { found in other reports made } \\
\text { by the Baznas of West } \\
\text { Kalimantan Province. }\end{array}$ \\
\hline
\end{tabular}

Journal of Islamic Accounting and Finance Research - Vol. 3 No. 1 (2021) 


\section{Baidhillah Riyadhi, Henri Prasetyo, Fiorintari}

JIAFR | 104

managed asset
designated for those
entitled, if any, the
amount and
percentage of all
infaq/shadaqah fund
usage and the
reasons thereof;
(g) details of the
amount of
infaq/shadaqah fund
disbursement
including the amount
of management
expenses and the
amount of funds
received directly by
the recipients of
infag/shadaqah;

(h) details of infaq/shadaqah

percentage of all

infaq/shadaqah fund

usage and the reasons

thereof;

details of the amount of

infaq/shadaqah fund

disbursement including

the amount of

management expenses

and the amount of

funds received directly

by the recipients of

infaq/shadaqah;

details of

infaq/shadaqah funds

based on the allocation,

restricted and

unrestricted; and

special relationship

between amil and

recipients of

funds based on the

allocation, restricted

infaq/shadaqah which

includes:

and unrestricted;

the character of the

and

special relationship;

(i) special

the amount and type of

relationship between

amil and recipients

assets distributed; and

of infaq/shadaqah

the percentage of

assets distributed from

which includes:

total disbursement

(i). the character of

the special

during the period.

relationship;

(ii). the amount and

type of assets

distributed; and

(iii). the percentage

of assets distributed

from total

disbursement during

the period.

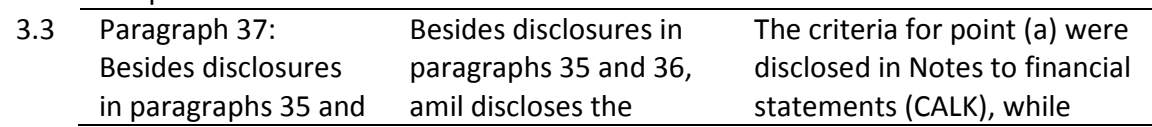

Journal of Islamic Accounting and Finance Research - Vol. 3 No. 1 (2021) 
Analysis of the implementation of Indonesia Financial Accounting Standards ...

\begin{tabular}{|c|c|c|}
\hline $\begin{array}{l}\text { 36, amil discloses the } \\
\text { following: } \\
\text { (a) the existence of } \\
\text { non-halal funds, if } \\
\text { any, is disclosed } \\
\text { regarding the } \\
\text { policies for the } \\
\text { receipt and } \\
\text { distribution of funds, } \\
\text { the reasons, and the } \\
\text { amount; and } \\
\text { (b) amil's } \\
\text { performance on the } \\
\text { receipt and } \\
\text { distribution of zakat } \\
\text { funds and } \\
\text { infaq/shadaqah } \\
\text { funds. }\end{array}$ & $\begin{array}{l}\text { following: } \\
\text { (a) the existence of } \\
\text { non-halal funds, if any, } \\
\text { is disclosed regarding } \\
\text { the policies for the } \\
\text { receipt and distribution } \\
\text { of funds, the reasons, } \\
\text { and the amount; and } \\
\text { (b) amil's performance } \\
\text { on the receipt and } \\
\text { distribution of zakat } \\
\text { funds and } \\
\text { infaq/shadaqah funds. }\end{array}$ & $\begin{array}{l}\text { point (b) was not disclosed in } \\
\text { the Financial Statements of } \\
\text { Baznas of West Kalimantan } \\
\text { Province, but was disclosed in } \\
\text { the Zakat Management } \\
\text { Report. } \\
\text { The conclusion regarding the } \\
\text { condition of Baznas of West } \\
\text { Kalimantan Province on this } \\
\text { criterion can be stated that it } \\
\text { is not in accordance with } \\
\text { PSAK } 109 .\end{array}$ \\
\hline
\end{tabular}

The results of the research in the disclosure section in table 3 show that the Baznas of West Kalimantan Province did not implement reporting in accordance with PSAK 109. Criteria that were not in accordance with PSAK 109 in the disclosure section are shown in table 3 no. 3.1, 3.2, and 3.3 which explains the absence of conformity to the implementation with PSAK 109. So it can be stated clearly that the Baznas of West Kalimantan Province does not implement reporting in accordance with PSAK 109 in the disclosure section.

\section{The Elements of Financial Statements}

The implementation of PSAK 109 in the elements of financial statements can be reviewed from the following table.

Table 4. The Implementation of PSAK 109 in the Elements of Financial Statements Section

\begin{tabular}{|c|c|c|c|}
\hline No. & PSAK 109 & Criteria & $\begin{array}{c}\text { Conditions in Baznas of West } \\
\text { Kalimantan Province }\end{array}$ \\
\hline 4.1 & $\begin{array}{l}\text { Attachment } \\
\text { Paragraph 2: } \\
\text { The elements of } \\
\text { financial statement } \\
\text { completely from amil }\end{array}$ & $\begin{array}{l}\text { The elements of } \\
\text { financial statement } \\
\text { completely from amil } \\
\text { consists of: } \\
\text { (a) balance sheet }\end{array}$ & $\begin{array}{l}\text { The criteria for the element } \\
\text { of financial statement of the } \\
\text { Baznas of West Kalimantan } \\
\text { Province are in accordance } \\
\text { with PSAK } 109 .\end{array}$ \\
\hline
\end{tabular}




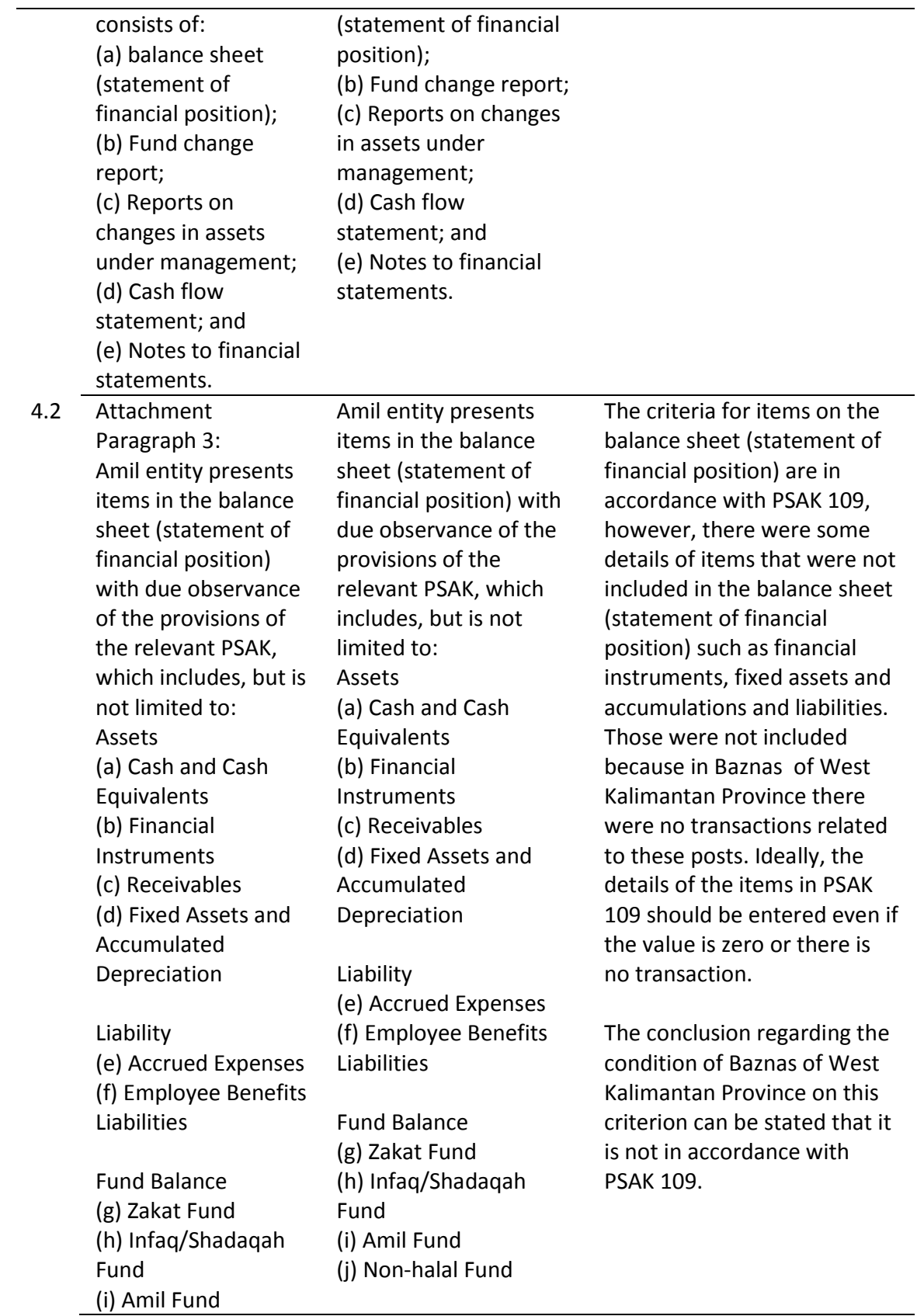


Analysis of the implementation of Indonesia Financial Accounting Standards ...

\begin{tabular}{|c|c|c|}
\hline (j) Non-halal Fund & & \\
\hline $\begin{array}{l}\text { Attachment } \\
\text { Paragraph 4: } \\
\text { Amil presents a } \\
\text { report on changes in } \\
\text { zakat funds, } \\
\text { infaq/shadaqah } \\
\text { funds, amil funds, } \\
\text { and non-halal funds. } \\
\text { The presentation of } \\
\text { fund change report } \\
\text { includes, but is not } \\
\text { limited to the } \\
\text { following items: } \\
\text { Zakat Fund } \\
\text { (a) Receipt of zakat } \\
\text { fund } \\
\text { (i) Part of zakat fund } \\
\text { (ii) Part of amil } \\
\text { (b) Distribution of } \\
\text { zakat fund } \\
\text { (i) Other amil entity } \\
\text { (ii) Other mustahiq } \\
\text { (c) Beginning balance } \\
\text { of zakat fund } \\
\text { (d) Ending balance of } \\
\text { zakat fund } \\
\text { Infaq/shadaqah Fund } \\
\text { (e) Receipt of } \\
\text { infaq/shadaqah fund } \\
\text { (i) Restricted } \\
\text { Infaq/Shadaqah } \\
\text { (muqayyadah) } \\
\text { (ii) Unrestricted } \\
\text { Infaq/Shadaqah } \\
\text { (mutlaqah) } \\
\text { (f) Distribution of } \\
\text { infaq/shadaqah } \\
\text { (i) Restricted } \\
\text { Infaq/Shadaqah } \\
\text { (muqayyadah) } \\
\text { (ii) Unrestricted } \\
\text { Infaq/Shadaqah } \\
\text { (n) }\end{array}$ & $\begin{array}{l}\text { Amil presents a report } \\
\text { on changes in zakat } \\
\text { funds, } \\
\text { infaq/shadaqah funds, } \\
\text { amil funds, and non- } \\
\text { halal funds. The } \\
\text { presentation of fund } \\
\text { change report includes, } \\
\text { but is not limited to the } \\
\text { following items: } \\
\text { Zakat Fund } \\
\text { (a) Receipt of zakat } \\
\text { fund } \\
\text { (i) Part of zakat fund } \\
\text { (ii) Part of amil } \\
\text { (b) Distribution of } \\
\text { zakat fund } \\
\text { (i) Other amil entity } \\
\text { (ii) Other mustahiq } \\
\text { (c) Beginning balance of } \\
\text { zakat fund } \\
\text { (d) Ending balance of } \\
\text { zakat fund } \\
\text { balance of zakat fund } \\
\text { Infaq/shadaqah Fund } \\
\text { (e) Receipt of } \\
\text { infaq/shadaqah fund } \\
\text { (i) Restricted } \\
\text { Infaq/Shadaqah } \\
\text { (muqayyadah) } \\
\text { (ii) Unrestricted } \\
\text { Infaq/Shadaqah } \\
\text { (mutlaqah) } \\
\text { (f) Distribution of } \\
\text { infaq/shadaqah } \\
\text { (i) Restricted } \\
\text { Infaq/Shadaqah } \\
\text { (muqayyadah) } \\
\text { (ii) Unrestricted } \\
\text { Infaq/Shadaqah } \\
\text { (mutlaqah) }\end{array}$ & $\begin{array}{l}\text { In the fund change report, } \\
\text { the items presented almost } \\
\text { fulfill the provisions in PSAK } \\
\text { 109. However, non-halal } \\
\text { funds were not separated but } \\
\text { combined with items of amil } \\
\text { fund. } \\
\text { The conclusion regarding the } \\
\text { condition of Baznas of West } \\
\text { Kalimantan Province on this } \\
\text { criterion can be stated that it } \\
\text { is not in accordance with } \\
\text { PSAK } 109 \text {. }\end{array}$ \\
\hline
\end{tabular}

JIAFR | 107 


\section{Baidhillah Riyadhi, Henri Prasetyo, Fiorintari}

JIAFR | 108

(mutlaqah)

(g) Beginning balance

of Infaq/Shadaqah

fund

(h) Ending balance of

Infaq/Shadaqah fund

Amil Fund

(i) Receipt of amil

fund

(i) Part of amil from

zakat fund

(ii) Part of amil from infaq/shadaqah

(iii) Other Receipt

(j) Use of amil fund

(i) General and

Administrative

Expenses

(k) Beginning balance

of amil fund

(I) Ending balance of amil fund

Non-halal fund

(m) Receipt of Non-

halal fund

(i) Interest

(ii) Giro Service

(iii) Other non-halal

Receipt

(n) Distribution of non-halal fund

(o) Beginning

balance of non-halal

fund

(p) Ending balance of

non-halal fund

\section{(g) Beginning balance of}

Infaq/Shadaqah fund

(h) Ending balance of

Infaq/Shadaqah fund

Amil Fund

(i) Receipt of amil fund

(i) Part of amil from

zakat fund

(ii) Part of amil from

infaq/shadaqah

(iii) Other Receipt

(j) Use of amil fund

(i) General and

Administrative

Expenses

(k) Beginning balance of amil fund

(I) Ending balance of

amil fund

Non-halal fund

(m) Receipt of Non-

halal fund

(i) Interest

(ii) Giro Service

(iii) Other non-halal

Receipt

(n) Distribution of non-

halal fund

(o) Beginning balance of non-halal fund

(p) Ending balance of non-halal fund

4.4 Attachment Amil entity presents a

Paragraph 5:

statement of assets

In Baznas, the statement of assets change under

Amil entity presents

change under

management was written

management which

with the statement of net

a statement of assets

change under

includes but is not

assets change, it was

management which limited to: recorded by classifying 
Analysis of the implementation of Indonesia Financial Accounting Standards ...

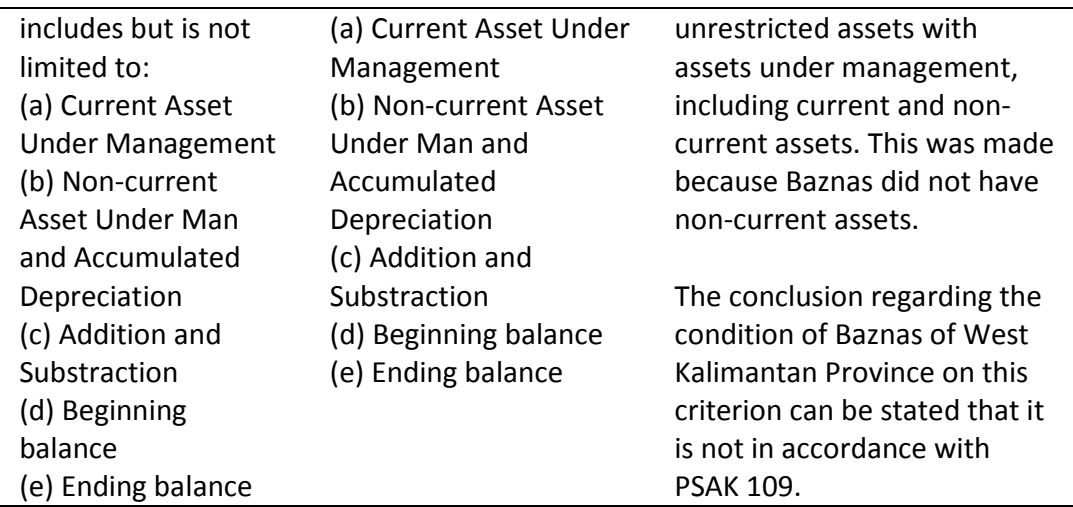

The results of the research on the components of the financial statements in table 4 show that the Baznas of West Kalimantan Province were not partly in accordance with the criteria and some of the criteria were in accordance with PSAK 109. The criteria in accordance with PSAK 109 in the elements of financial statements are shown in table 4 no. 4.1 and 4.2 which explain the suitability with the implementation of PSAK 109. While the criteria that were not in accordance with PSAK 109 in the elements of financial statements are shown in table 4 no. 4.3 and 4.4 which explain that were not in accordance with the implementation of PSAK 109. So it can be stated clearly that the Baznas of West Kalimantan Province does not implement reporting in accordance with PSAK 109 in the elements of financial statements section.

\section{Conclusion}

The results of research related to the application of PSAK 109 at Baznas of West Kalimantan Province in compiling financial statements through the data that have been collected show the suitability and non-conformity of the implementation on the criteria established in accordance with PSAK 109.

Based on the analysis carried out, it can be concluded that: 1) The implementation of PSAK 109 in the recognition and measurement section at Baznas of West Kalimantan Province can be stated in accordance with PSAK 109. 2) The implementation of PSAK 109 in the presentation, disclosure and elements of financial statements at Baznas of West Kalimantan Province has 
not fully implemented PSAK 109 as a whole. 3) There are efforts by the Baznas of West Kalimantan province to implement PSAK 109.

The limitations of this research are related to the criteria that have been formulated in the application of PSAK 109 that cannot be fully discussed due to the absence of events that occurred in the Baznas of West Kalimantan Province, such as: there were no non-cash asset receipt transactions. So that there are several criteria that cannot be discussed in determining the suitability of reporting implementation based on PSAK 109. Suggestions for further research, researchers can first ask the object of research, whether events related to the criteria that have been arranged have occurred in the object of research to be studied. Therefore, researchers can discuss thoroughly based on the criteria that have been prepared to be able to determine the suitability of the implementation of PSAK 109 to the object of research.

\section{References}

Affandi, I., \& Riswanto. (2018). Pelaporan Ziswaf pada LAZ al Hijrah Kota Medan berdasarkan PSAK 109. KITABAH, 2(1), 102-128.

Asnaini, A. (2017). Pengelolaan Zakat Oleh Negara-Badan Amil Zakat (BAZ)(Studi Terhadap Sikap Muzakki di Kota Bengkulu). Jurnal BAABU AL-ILMI: Ekonomi Dan ..., 2(1), 1-15. https://ejournal.iainbengkulu.ac.id/index.php/alilmi/article/view/15 79.

Arwani, A. (2020). Sharia accounting on Indonesian Financial Accounting Standard on zakat and waqf take on industrial revolution 4.0 and society era 5.0.Journal of Islamic Accounting and Finance Research, 2(2), 229-258. doi:http://dx.doi.org/10.21580/jiafr.2020.2.2.6295.

Fathony, A. A., \& Fatimah, I. (2017). Pengaruh Penerapan Psak 109 Dan Uu Nomor 23 Tahun 2011 Tentang Pengelolaan Zakat Terhadap Akuntabilitas Publik Di Lembaga Amil Zakat Pusat Zakat Umat Persis Bandung. Akurat - Jurnal Ilmiah Akuntansi - Universitas Bale Bandung, 8(1), 10-21. http://ejournal.unibba.ac.id/index.php/AKURAT. 
Analysis of the implementation of Indonesia Financial Accounting Standards ...

Irwanto. (2019). Potensi Zakat di Kalbar Mencapai 2.104 Triliun. Berita Kanwil Kemenag Kalbar. https://kalbar.kemenag.go.id/id/berita/potensizakat-di-kalbar-mencapai-2104-triliun.

Mahmudi. (2008). Pengembangan Sistem Akuntansi Zakat dengan Teknik Fund Accountin. Idb2.Wikspaces.Com, 38, 1-9. http://idb2.wikispaces.com/file/view/rp2008.pdf.

Ngoyo, M. F., \& Bulutoding, L. (2016). Kajian Penerapan Akuntansi Zakat dan Infaq/Sedekah berdasarkan Psak 109 pada Badan Amil Zakat Nasional (Baznas) Kota Makassar. Jurnal Iqtisaduna, 2(2).

Nurhasanah, S. (2018). Akuntabilitas Laporan Keuangan Lembaga Amil Zakat Dalam Memaksimalkan Potensi Zakat. Akuntabilitas, 11(2), 327-348. https://doi.org/10.15408/akt.v11i2.8826.

Nurhayati, S. (2013). Akuntansi Syariah di Indonesia (Edisi 3). Salemba Empat: Jakarta.

PSAK 109 Akuntansi Zakat dan infak/Sedekah. (2018). http://iaiglobal.or.id/v03/standar-akuntansi-keuangan/pernyataansas-72-psak-syariah-109.

Rahman, T. (2015). Akuntansi Zakat, Infak dan Sedekah (PSAK 109): Upaya Peningkatan Transparansi dan Akuntabilitas Organisasi Pengelola Zakat (OPZ). Muqtasid: Jurnal Ekonomi Dan Perbankan Syariah, 6(1), 141. https://doi.org/10.18326/muqtasid.v6i1.141-164.

Ritonga, P. (2017). Analisis Akuntansi Zakat berdasarkan PSAK No. 109 pada Badan Amil Zakat Nasional (Baznas) Sumatera Utara. KITABAH, 1(1), $1-12$.

Rizal, Fitri, S. A., \& Minazzulami, H. (2017). PSAK 109: A Study Of Its Application At BAZNAS Solok Regency. Jurnal IMARA, 1(1), 1-16.

Rulian, N. A., Anggraeni, L., \& Lubis, D. (2014). Faktor-Faktor yang Memengaruhi Muzaki dalam Memilih OPZ: Studi Kasus BAZNAS Kota Bogor. Republika Online. https://republika.co.id/berita/n4iu031/faktorfaktor-yangmemengaruhi-muzaki-dalam-memilih-opz-studi-kasus-baznas-kotabogor.

Undang-Undang Nomor 23 Tahun 2011 tentang Pengelolaan Zakat.pdf, (2011). 
Baidhillah Riyadhi, Henri Prasetyo, Fiorintari

Wahyudi, D. I. (2020, November). Seberapa Besar Potensi Zakat di Indonesia. Buletin Baznas Provinsi Kalbar, Edition 12/Th.XI/2020, 5.

JIAFR | 112 